\title{
9. THERMAL REGIME OF THE NORTHERN BAY OF BISCAY CONTINENTAL MARGIN IN THE VICINITY OF DSDP SITES 400 TO 402'
}

\author{
Jean-Paul Foucher and Jean-Claude Sibuet, Centre Océanologique de Bretagne, B.P. 337, 29273, Brest, France
}

\section{INTRODUCTION}

- Ten conventional oceanic surface heat flow measurements were made over the northern margin of the Bay of Biscay in the vicinity of the DSDP Sites 400 to 402 during the R/V Suroit - SU 01 (December 1975) and R/V Jean Charcot - CH 66 (February 1976) cruises of CNEXO. These measurements, complemented by the heat flow determination made at Site 402 during Leg 48 of the Deep Sea Drilling Project (Erickson et al., this volume) provide information on the thermal regime of the margin. The main observation is that the regional heat flux over the margin is substantially lower than over the adjacent Western European continental area. We suggest in this report that the observed heat flux contrast provides constraints on the debatable nature of the crustal thinning processes under the margin. -

\section{REGIONAL SETTING}

The study area lies north of the Bay of Biscay over the Western Approaches margin, in the vicinity of DSDP Sites 400 to 402 (Figure 1). Extensive geological and geophysical work (e.g., Auffret et al., Montadert et al., Avedik and Howard, this volume) as well as drilling results (this volume) have provided detailed information on the structure of the margin. Under a thin Upper Cretaceous to Cenozoic sediment cover of 1 to $2 \mathrm{~km}$ thickness, a series of tilted fault blocks extend from the mid-continental slope to the abyssal plain down to the Trevelyan Escarpment at a depth of about $4 \mathrm{~km}$ (Figure 2). The fault blocks trend subparallel to the margin, controlling the relief of the Meriadzek Terrace, and are bounded by listric faults that become near horizontal at a depth of about 4 to $5 \mathrm{~km}$ below the sediment surface (Montadert et al., this volume). They consist of Mesozoic sediments (drilled at Site 401 ) and/or Hercynian basement rocks (dredged at the base of Goban Spur at about $4 \mathrm{~km}$ depth (Pautot et al., 1976]). It is now widely agreed that the fault block structure of the margin was shaped mainly during the rifting episode that is dated as Late Jurassic/Early Cretaceous, and preceded the onset of the opening of the Bay of Biscay in the upper Aptian. Structural interpretation and geophysical results suggest that the continental oceanic crust boundary lies south of the Trevelyan Escarpment (Figure 1) (Montadert et al., Avedik and Howard, this volume). Under the Trevelyan Escarpment, seismic refraction data indicate that the Moho lies at a depth of 12 to $13 \mathrm{~km}$ compared to 27 to $30 \mathrm{~km}$ under the continental shelf

'Contribution 629 of the Centre Océanologique de Bretagne (Department of Marine Geology, Geophysics and Geochemistry).
(Avedik and Howard, this volume) implying a considerable thinning of the original continental crust.

Six of the ten surface heat flux measurements reported here form a transect from the mid continental slope to the abyssal plain across the Meriadzck Trevelyan area; the four other measurements are located over the northwestern termination of the Meriadzek Terrace known as the Acgis Ridge. DSDP Site 402 heat flux determination was located slightly higher on the slope (Figure 3 ).

\section{SURFACE GEOTHERMAL DATA}

The temperature gradients were determined from the temperatures measured at up to five different depths in the 2 to 10 upper meters of sediment; thermistor temperature probes attached at known vertical distances along the 10-meter long barrel of a piston corer were used to make the measurements (Gerard et al., 1962). At each site the temperature of each probe was measured about every 10 seconds, for a total period of about 6 minutes, during which the corer was left undisturbed in the sediment. The recording device, of the wheatstone bridge and film recording type (Lamont-type) described by Langseth (1965), was housed in a pressure vessel at the top of the corer. Equilibrium temperatures in the sediment were extrapolated from the temperature transients recorded by linear fitting of the temperatures versus the reciprocal of time (Bullard, 1954). The accuracy of the temperatures determined in the sediment with respect to the bottom water temperature is a few thousandths of ${ }^{\circ} \mathrm{C}(<0.005)$. The uncertainty of the bottom water temperatures is $\pm 0.02^{\circ} \mathrm{C}$.

The thermal conductivity of the sediment was measured on board the ship at several points along each core recovered, in most cases every $50 \mathrm{~cm}$, using the transient needle probe technique (von Herzen and Maxwell, 1959) and correcting the values to in-situ temperature and pressure conditions (Ratcliffe, 1960). The accuracy of the needle probe technique has been estimated to 3 to 4 per cent (von Herzen and Maxwell, 1959). However, larger errors occasionally occur due to mechanical disturbances of the sediment either during the coring operation itself or afterwards, while handling the core on board the ship. In practice, conductivity values departing significantly from the trend defined by the other values were eliminated in the absence of notable apparent changes in the lithology of the sediment.

The temperature profiles in the sediment are linear to a first approximation (Figures 4 and 5). The linearity is in particular indicated by the agreement between the extrapolated surface sediment temperatures and the measured bottom water temperatures (Table 1). Pronounced curvatures downwards were, however, observed at station 


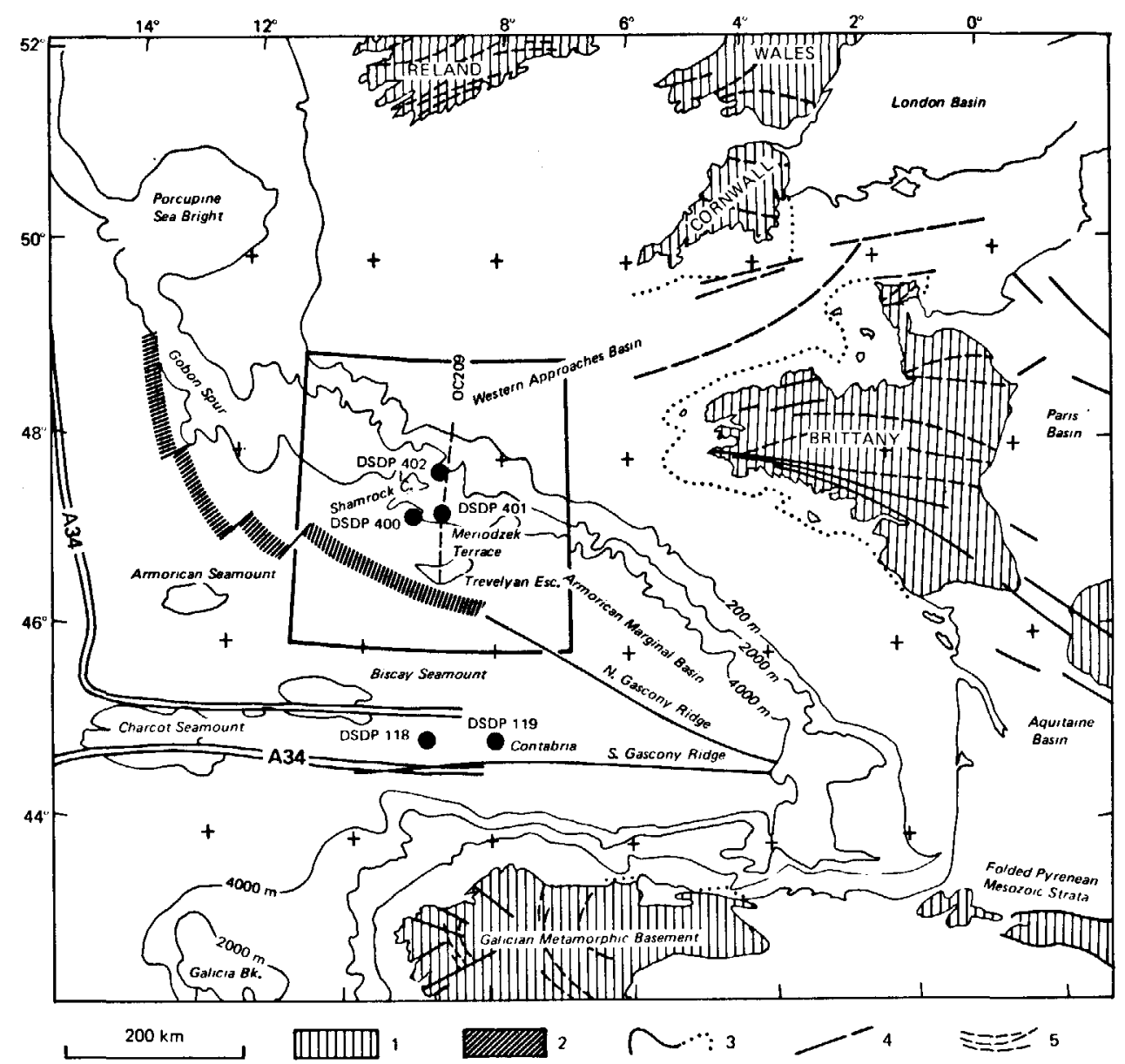

Figure 1. Main physiographic features of western Europe and of the Bay of Biscay after Montadert et al. (this wolume). Magnetic anomaly 34 after Sibuet et al. (in press). The hatched area shows the continental/oceanic crust boundary (Montadert et al., this volume). (1) Hercynian ranges and Paleozoic basins. (2) Continent/ocean boundary (Montadert et al., this volume). (3) Boundaries of inshore basins. Blank areas inland represent the Mesozoic and Cenozoic basins. (4) Main fractured zones and faults. (5) Main Hercynian fold trends.

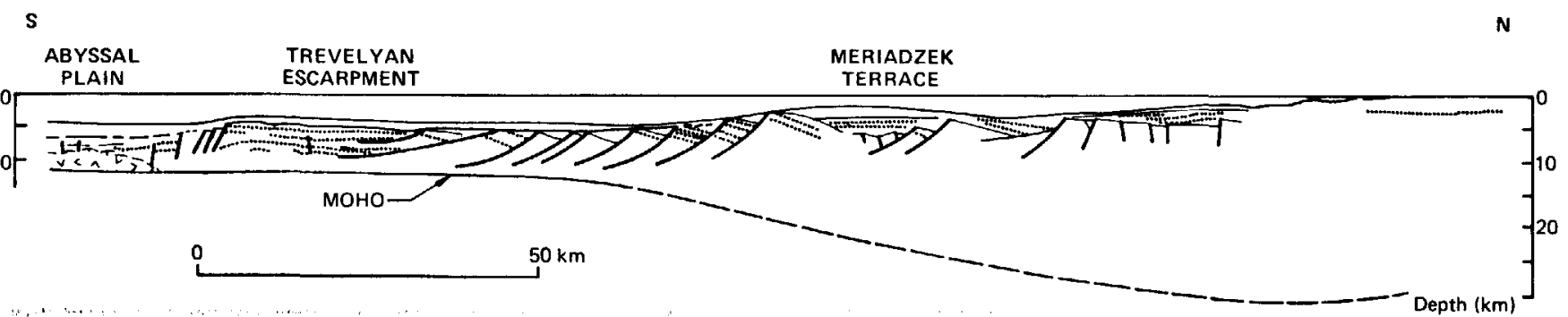

Figure 2. Cross-section of the Western Approaches continental margin along seismic reflection profile OC 209 after Montadert et al. (this volume). Location of profile in Figure 1.

CH 66-08 over Trevelyan (Figure 4) and stations $\mathrm{CH} 66-14$, CH 66-15, and $\mathrm{CH} 66-16$ over the Aegis Ridge (Figure 5). Bottom water temperature fluctuations may be one possible explanation of the curvature (e.g., Pugh, 1975), but in the absence of available long-term bottom water temperature records, this explanation remains hypothetical. One will note that at station $\mathrm{CH} 66-15$, where the maximum difference between the extrapolated and measured bottom water temperatures occurs, the four temperature points at sub-bottom depths between 1.5 and 5.9 meters are nearly perfectly aligned. If the curvature of the temperature profile at station $\mathrm{CH}$ 66-15 results from bottom water temperature fluctuations, the shape of the temperature profile then suggests that these fluctuations are of short period (periods 


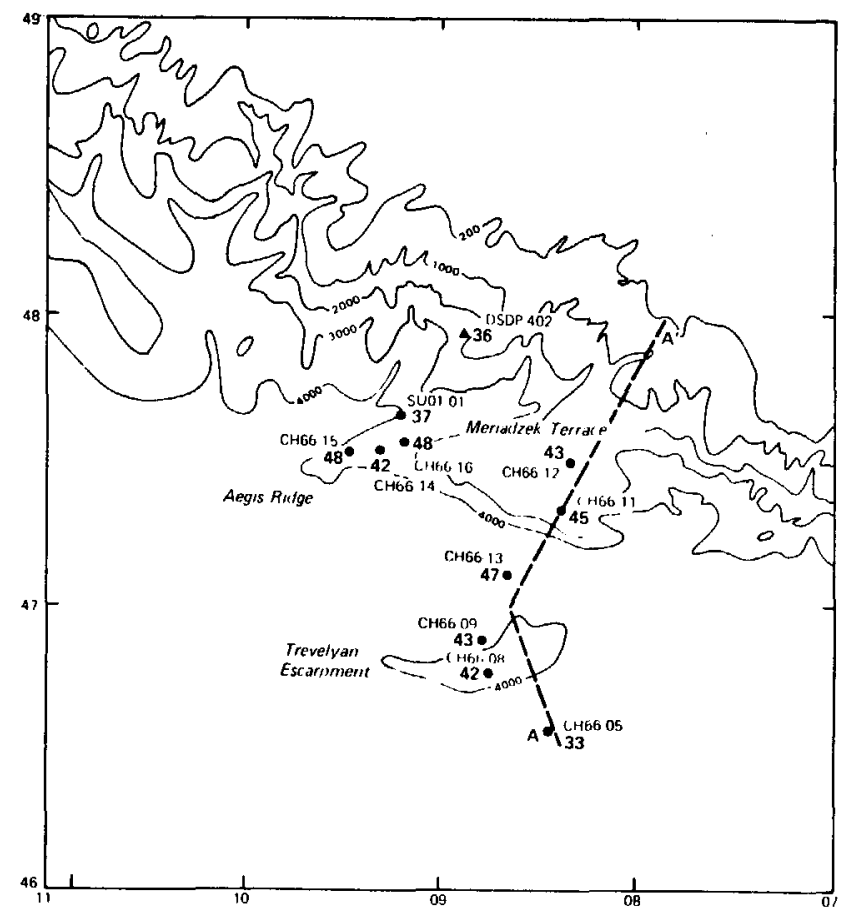

Figure 3. Location map of the CNEXO heat flow measurements over the Western Approaches continental margin. The DSDP Site 402 heat flow determination is shown by a triangle. The heat flow values are in $\mathrm{mWm}^{-2}$.

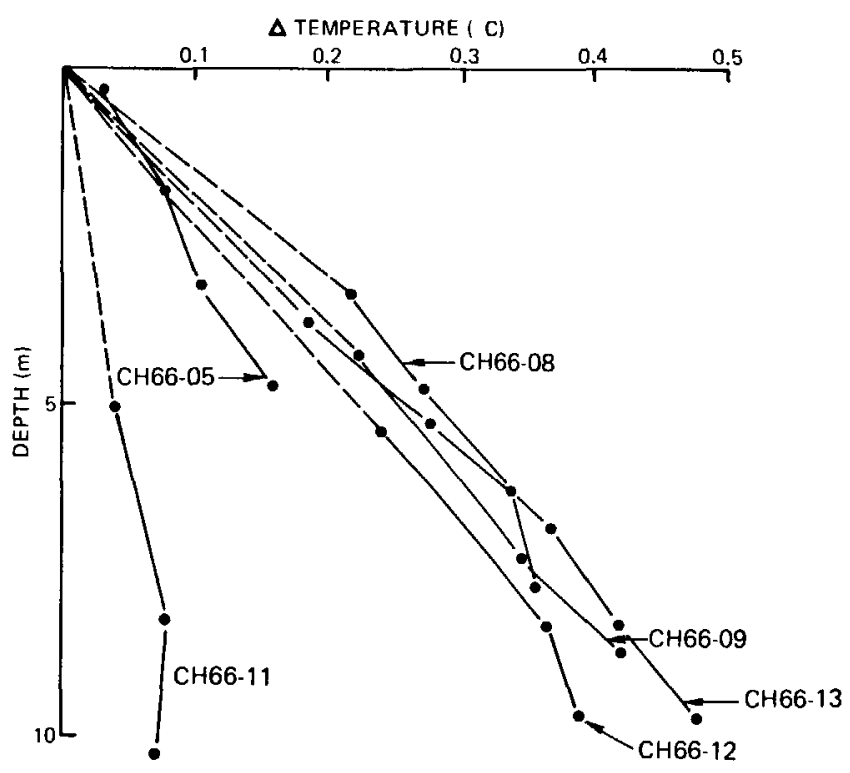

Figure 4. Temperature profiles in sediment at stations located along profile $A A^{\prime}$ (Figure 3). Note the anomalously low gradient at station $\mathrm{CH}$ 66-11. Temperatures are relative to the bottom water temperature at each station.

of a few days or weeks) penetrating only to small depths in the sediment (Pugh, 1975). The occurrence of short-term bottom water temperature fluctuations may be related to an instability of the water masses along the slope of the margin. In the absence of any evidence on which to rely, for

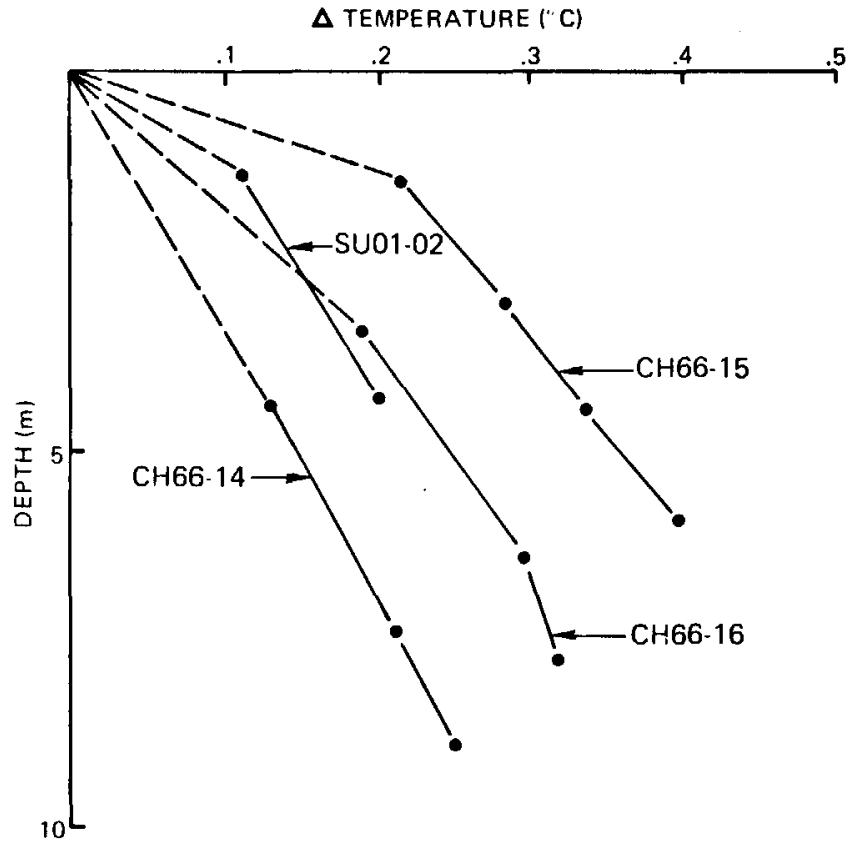

Figure 5. Temperature profiles in sediment for the four stations over the Aeg is Ridge. Temperatures are relative to the bottom water temperature at each station.

applying corrections to the observed temperature profiles, no correction has been made. We consider the stations where pronounced curvatures of the temperature profiles are observed as being of moderate quality.

Table 1 summarizes the data obtained. The heat flow value at each station is simply taken as the product of the mean vertical temperature gradient and the mean harmonic thermal conductivity. The corrected heat flow values include corrections applied to account for the effects upon the near-surface temperature gradients of the large-scale topographic variations across the margin (topographic corrections in Table 1 ) and of the sedimentation (sedimentary corrections in Table 1). Topographic corrections were computed by solving the two-dimensional steady-state heat conduction equation (Sclater and Miller, 1970) applied to topographic profiles across the margin (Figure 6). Topographic corrections are typically a few per cent, with a maximum of -11 per cent at station $\mathrm{CH} \mathrm{66-13} \mathrm{at} \mathrm{the} \mathrm{top} \mathrm{of}$ the Aegis Ridge. Sedimentary corrections were calculated using the von Herzen and Uyeda (1963) procedure, adopting a thermal diffusivity value of $3 \times 10^{-3} \mathrm{~cm}^{2} / \mathrm{s}$ (von Herzen and Maxwell, 1959). For a total sedimentary thickness of 1 to $2 \mathrm{~km}$, assumed to have been deposited at a uniform rate over the Meriadzek Trevelyan area since the end of rifting $(110 \mathrm{~m} . \mathrm{y}$.$) , the correction amounts to 3.3$ to 6.6 per cent. Over the Aegis Ridge, sediments are lacking or reduced for the period ranging from $110 \mathrm{~m}$.y. to $60 \mathrm{~m}$.y. Assuming then that the approximately $1-\mathrm{km}$-thick sediments have been deposited over the last $60 \mathrm{~m} . \mathrm{y}$., the correction amounts to 4.5 per cent. A 5 per cent average correction was applied to all measurements (Table 1). The total correction at each station does not exceed 15 per cent which justifies the simple correction procedures adopted above. The uncertainty on the corrected heat flow values is estimated to \pm 20 per cent. 


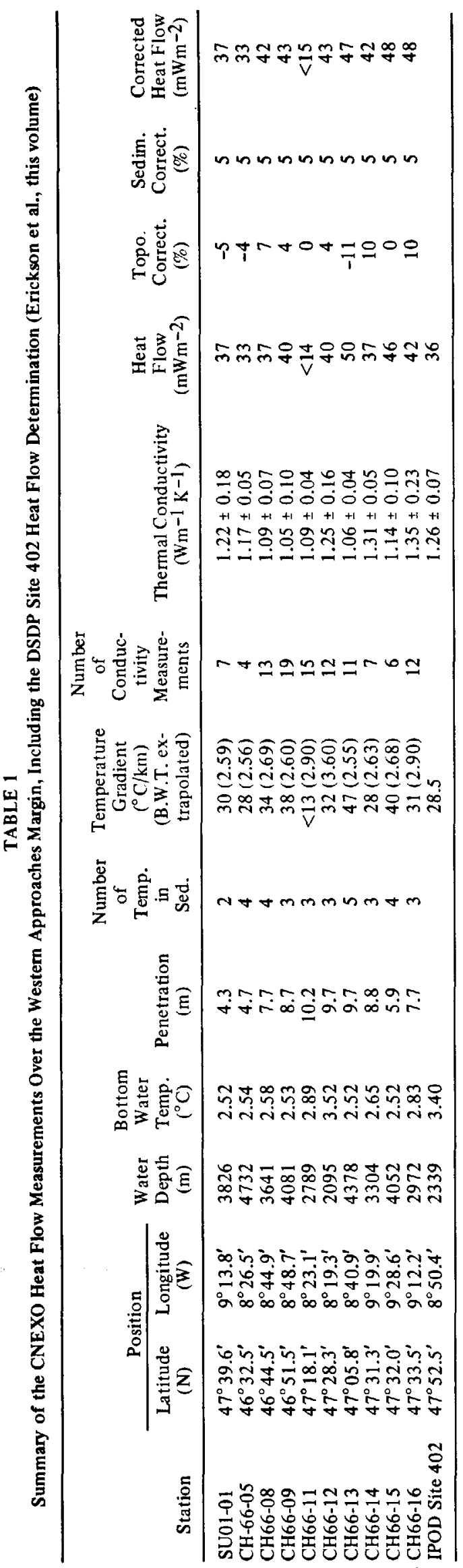

\section{RESULTS}

Excluding station $\mathrm{CH}$ 66-11 where we have measured an abnormally low conductivity heat flow, the mean conductive heat flow value calculated for the other nine stations is $43 \pm 5$ (s.d.) $\mathrm{mWm}^{-2}$. There is no apparent trend in the heat flow distribution across the margin, with the exception, however, of a slightly lower value of $33 \mathrm{mWm}^{-2}$ at station $\mathrm{CH} \mathrm{66-05}$ at the foot of the Trevelyan Escarpment, in close proximity to the oceanic crust, which requires confirmation by further measurements. The surface heat flow data are in good agreement with the heat flow determination of $36 \pm 14 \mathrm{mWm}^{-2}$ reported for the DSDP Site $\mathbf{4 0 2}$ located slightly higher on the slope (Erickson et al., this volume). The thermal regime of the Western Approaches continental slope and rise appears then to be characterized by a low and fairly uniform regional heat flux of the order of 36 to $43 \mathrm{mWm}^{-2}$. The exceptionally low conductive heat flux measured at station $\mathrm{CH}$ 66-11 may indicate that conduction is not the dominant heat transfer process in the vicinity of this station. One may suggest, therefore, the occurrence of convective heat transfer along faults at the edge of the Meriadzek Terrace.

COMPARISON WITH HEAT FLUX DATA OF THE ADJACENT CONTINENTAL AND OCEANIC AREAS

Figure 7 shows the compilation of the available heat flux data in western Europe and the Bay of Biscay. Included are the surface heat flow data obtained over the Western Approaches margin reported here and the heat flow determinations at DSDP Site 402 (Erickson et al., this volume). The compilation is based on the world heat flow data compilation by Jessop et al. (1976) and for data in France on recent compilations made by Gable $(1977)$ and Bertaux et al. (1978). One observes that the background heat flux in France over stable portions of the Hercynian continental crust is of the order of 65 to $85 \mathrm{mWm}^{2}$. This range of values is comparable with the $72.5 \pm 19.8$ (s.d.) $\mathrm{mWm}^{2}$ heat flux average calculated for the Hercynian fold belt in central Europe from a total of 147 measurements (Hurtig and Oelsner, 1977). In southwest England, a similar value of $67 \mathrm{mWm}^{-2}$ was obtained while the two other exceptionally high values, of 134 and $137 \mathrm{mWm}^{2}$, are thought to be due partly to a high crustal radioactivity associated with the Cornwall batholith and partly to hydrothermal effects (Tammemagi and Wheildon, 1974). Compared to the background heat flux in western Europe, the heat flux over the Western Approaches margin appears then to be reduced by nearly a factor of two. In contrast, heat flow values over the margin are similar to those in the Bay of Biscay. The average of the five available heat flux values in the Bay of Biscay is $45 \pm 10$ (s.d.) $\mathrm{mWm}^{-2}$.

\section{IMPLICATIONS}

We can first remark that the time since the last major thermal event affected the Western Approaches margin, dated at $100 \mathrm{~m} . \mathrm{y}$., corresponding to the end of rifting before the onset of opening of the Bay of Biscay in late Aptian time, is considerably more than the thermal time constant of the lithosphere that is a few tens of millions of years. This implies that the Western Approaches margin is close to 

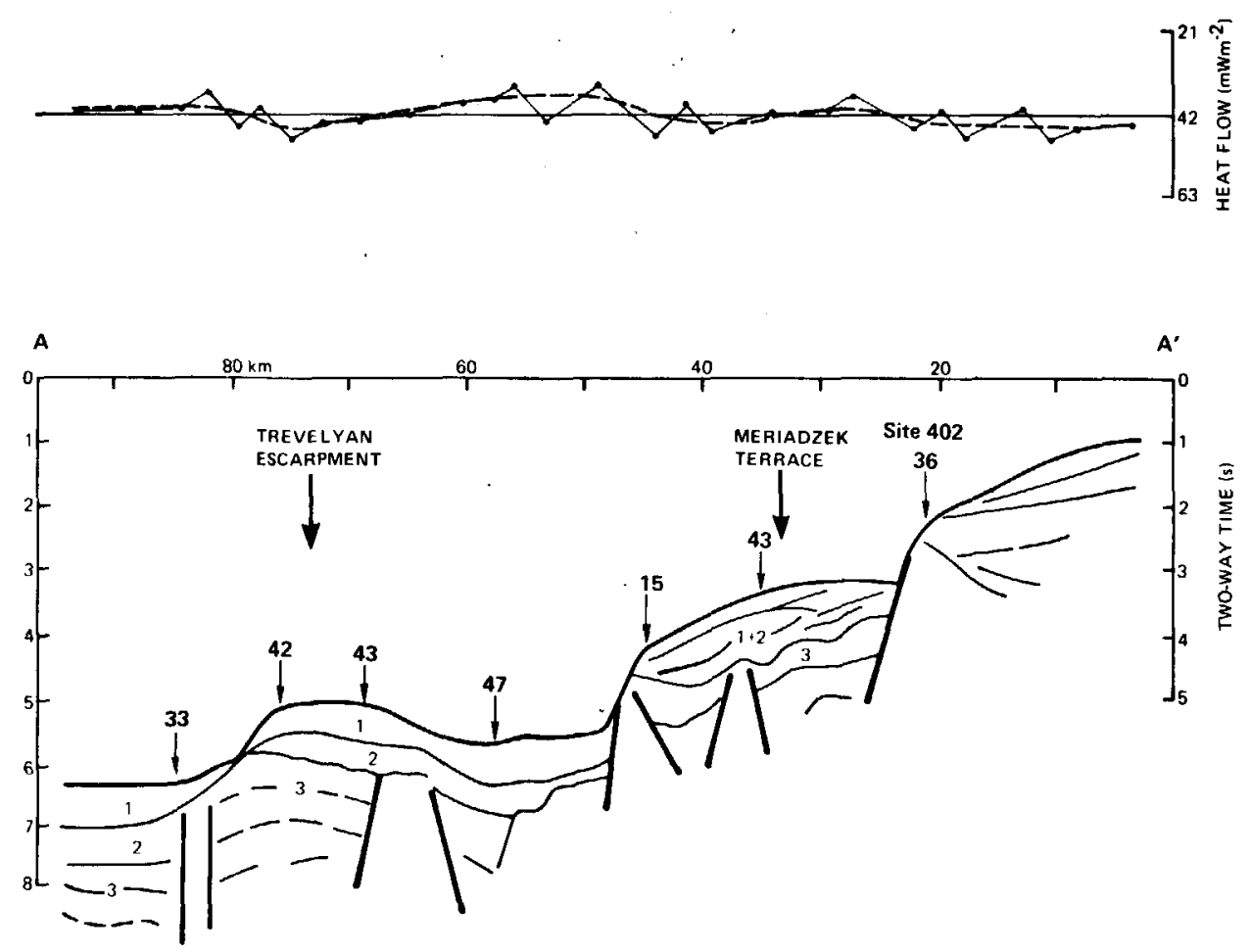

Figure 6. Bottom: Corrected heat flow measurements superimposed on the interpretated seismic profile AA' from Montadert et al. (1974) located in Figure 3. Sedimentary units as follows: (1) Post-Eocene, (2) Cenomanian to Eocene, (3) Aptian/Albian. Top: Effects of the topography on the surface heat flux assuming a constant heat flux at depth of $42 \mathrm{mWm}^{-2}$. The dotted line is a smoothed curve.

thermal equilibrium. This is true all the more for the stable Hercynian continental area where the time since the last major thermal event to have affected the lithosphere $(\approx 280$ m.y.) is still larger. Close to steady-state thermal conditions therefore characterize the thermal regime of both the Western Approaches margin and the adjacent western European continental area. The steady-state surface heat

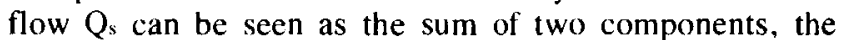
crustal radioactive heat production $Q_{c}$ and the heat flux from the mantle $\mathrm{Q}_{\mathrm{m}}$. If one neglects the lithospheric mantle radioactive heat production that is unlikely to exceed a few $\mathrm{mWm}^{-2}$ (e.g., Bickle, 1978) the mantle heat flux is, to a first approximation, the heat flux at the base of lithosphere. Consequently, the heat flux contrast observed between the Western Approaches margin and the adjacent stable Hercynian western European continental area can be explained in terms of either different crustal contributions or different heat flux at the base of the lithosphere, or yet, a combination of these two reasons. Because both the Western Approaches margin and the adjacent continent belong to the same stable portion of the European plate, we see a priori no reason why the heat flux at the base of the lithosphere should vary from one area to the other, so that the second explanation appears to be less likely. We therefore suggest that the observed heat flux contrast reflects different crustal contributions.

Table 2 illustrates our approach in providing tentative estimates of the crustal contributions $Q_{c}$ and the mantle heat flux $Q_{m}$ for the Western Approaches margin and the adjacent continental and oceanic areas. The 24 to 30 $\mathrm{mWm}{ }^{2} \mathrm{Q}_{\mathrm{m}}$ value used for western Europe, also adopted for the Western Approaches margin, is the estimate derived by Daignères and Vasseur (in press) for the Bournac site in the Central Massif in France. At this site the measured surface heat flow is $85 \mathrm{mWm}^{-2}$, so that about two-thirds of the surface heat flux would be accounted for by crustal radioactivity. Based on the 24 to $30 \mathrm{mWm}^{-2} \mathrm{Q}_{\mathrm{m}}$ value derived at the Bournac site which is, to our knowledge, the only $Q_{m}$ estimate available in western Europe, the crustal contribution for the Western Approaches margin therefore would be only a part between 0.11 and 0.46 of the crustal contribution for western Europe (Table 2). Allowing for some uncertainty in the $Q_{m}$ value, because the regional validity of the Bournac site estimate can be questioned, one can note that a higher $Q_{m}$ value still would increase the amount of reduction of the crustal contribution, whereas an upper limit of the possible amount of reduction is given by the case of the mantle heat flux taken equal to zero: $Q_{c}(L) /$ $\mathrm{Q}_{\mathrm{c}}\left(\mathrm{Lo}_{\mathrm{o}}\right)$ would be then equal to $\mathrm{Qs}_{\mathrm{s}}(\mathrm{L}) / \mathrm{Q}_{\mathrm{s}}\left(\mathrm{Lo}_{\mathrm{o}}\right)$ and would lie between 0.42 and 0.66 .

If the above approach is correct, an important implication of the heat flow results is to require crustal thinning processes under the margin capable to produce a large reduction of the crustal radioactive heat production. Figure 8 illustrates schematically the possibility of four main types of crustal thinning to decrease the crustal radioactive heat production. One fundamental preliminary observation is that if crustal thinning reflects only an upward migration of 


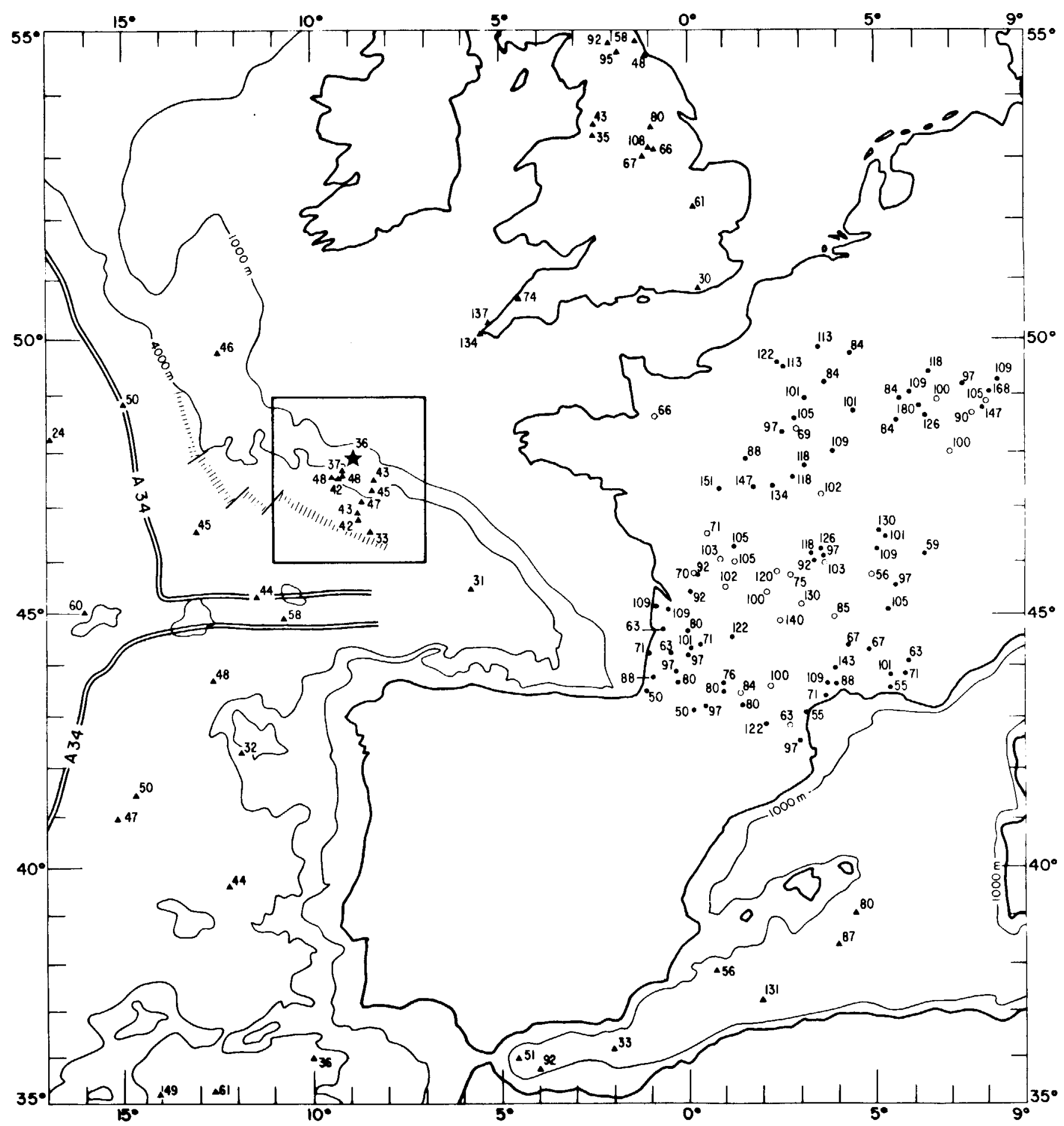

Figure 7. Compilation map of the available heat flow data in western Europe and the Bay of Biscay sources: Jessop et al., 1976 (triangles); Gable, 1977 (full circles); Bertaux et al., 1978 (open circles); Erickson et al., this volume (star);this study (triangles in the box). The hatched area shows the continental/oceanic crust boundary.

the Moho as a result of deep metamorphic changes such as gabbro to eclogite (Ringwood and Green, 1966: Colette, 1968) or greenshist to amphibolite (Falvey, 1974), no variation is expected in the steady-state surface heat flux insofar as each lithospheric column may be considered as a closed system for the radiogenic sources contained in this column (Figure 8, Curve A). In other words we assume that there is no lateral migration of the radiogenic sources and no input of new radiogenic sources from below. Applied to the Western Approaches margin, this means that deep metamorphism processes are unlikely to be the dominant cause of the crustal thinning hecause these processes would not account for the large reduction of the surface heat flow. In contrast to deep metamorphism, the three other processes considered in Figure 8 can produce a significant decrease of the crustal radioactive contribution. One of these processes 
TABLE 2

Estimates of the Surface Heat Flow $Q_{s}$, the Crustal Contribution $Q_{c}$ and the Mantle Heat Flux $Q_{m}$ for the Western Approaches Continental Slope and Rise and the Adjacent Oceanic and Continental Areas ${ }^{2}$

\begin{tabular}{lccc}
\hline & $\begin{array}{c}\text { Bay of Biscay } \\
\text { Oceanic Crust }\end{array}$ & $\begin{array}{c}\text { Western Approaches } \\
\text { Continental Slope }\end{array}$ & $\begin{array}{c}\text { West European Hercynian } \\
\text { Continental Crust }\end{array}$ \\
\hline $\begin{array}{l}\text { Age of last } \\
\text { thermal event } \\
(\mathrm{m} \cdot \mathrm{y} .)\end{array}$ & $70-110$ & 110 & 280 \\
$\mathrm{O}_{\mathrm{s}}\left(\mathrm{mWm}^{-2}\right)$ & $35-55$ & $36-43$ & $65-85$ \\
$\mathrm{O}_{\mathrm{m}}\left(\mathrm{mWm}^{-2}\right)$ & $(25)^{\mathrm{a}}$ & $24-30$ & $24-30$ \\
$\mathrm{Q}_{\mathrm{c}}\left(m \mathrm{~mm}^{-2}\right)$ & $(10-30)$ & $6-19$ & $35-61$ \\
$\mathrm{Q}_{\mathrm{c}}(\mathrm{L}) /$ & & & $0.11-0.46$ \\
$\mathrm{Q}_{\mathrm{c}}\left(\mathrm{L}_{\mathrm{o}}\right)$ & & & \\
\hline
\end{tabular}

a The $25 \mathrm{mWm}^{-2} \mathrm{Q}_{\mathrm{m}}$ value given for the Bay of Biscay is a mean estimate for the oceanic regions (Kono and $Y_{0}$ oshii, 1975).

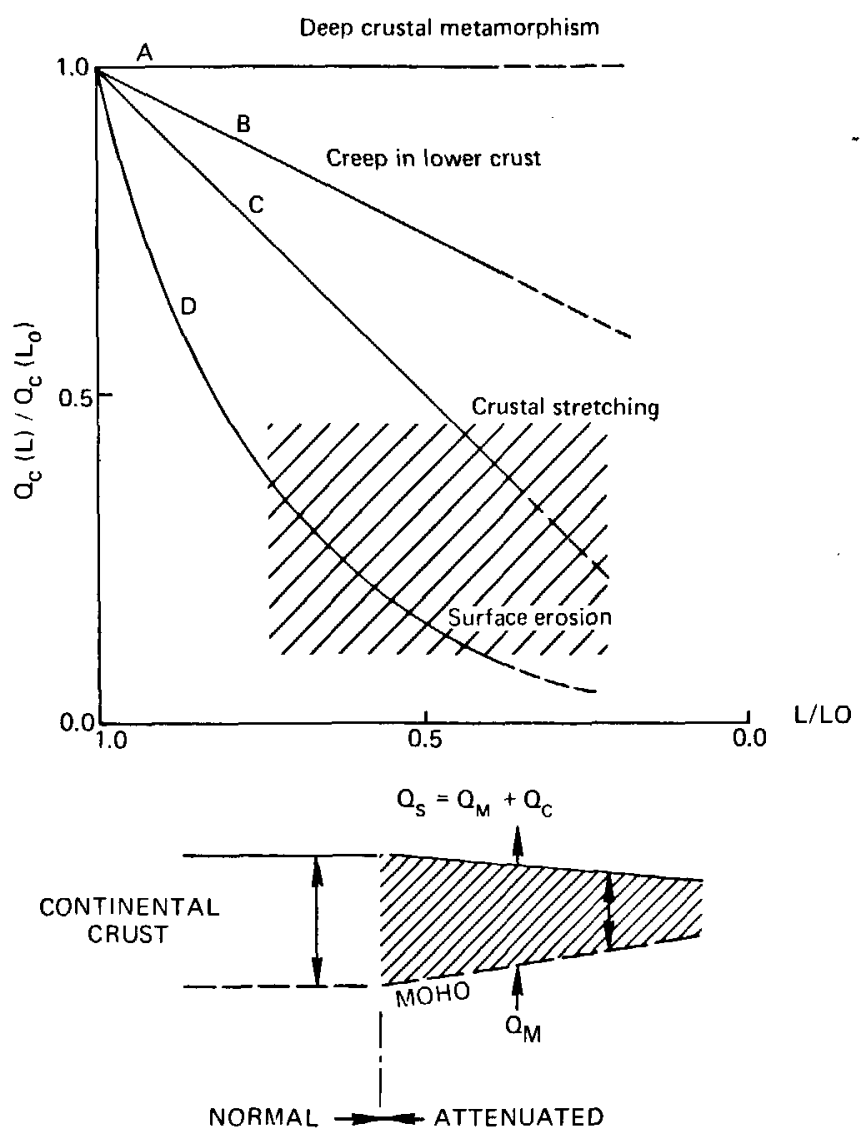

Figure 8. Predicted change in the crustal contribution to the surface heat flow assuming various mechanisms of crustal thinning (A) Deep crustal metamorphism (Falvey, 1974; Ringwood and Green, 1966; Colette, 1968); (B) Creep in lower crust (Artemjev and Artyushkov, 1971; Bott and Dean, 1972); (C) Crustal stretching (Artemjev and Artyushkov, 1971; Morton and Black, 1975); (D) Surface erosion (Sleep, 1971). $Q_{c}$ and $Q_{m}$ are, respectively, the crustal and mantle contributions to the surface heat flow $Q_{S^{\circ}}$ Lo and $L$ are thicknesses of, respectively, the normal and thinned continental crust. The hatched area gives the window corresponding to the heat flow constraints (see text). is surface erosion generally related to doming of the continental crust in the early stage of formation of a rifted margin (Closs, 1939; Sleep, 1971). If radiogenic sources are mainly concentrated in the upper crustal material, as generally believed (e.g., Roy et al., 1968; Lachenbruch, 1968 ), surface erosion is expected to cause a rapid decrease of the crustal contribution because it would remove the more radiogenic crustal material (Figure 8, Curve D). However, the loss of radiogenic sources during erosion can be compensated to some extent by the radioactive contribution of the sediments deposited after erosion. The two other processes considered in Figure 8 involve a purely mechanical deformation of the crust under tensional forces developed either during rifting (Artemjev and Artyushkov, 1971: Morton and Black, 1975) or in the early stage of opening of a new ocean as a result, in this latter case, of unequal loading and associated isostatic compensation across the margin (Bott, 1971; Bott and Dean, 1972). The extension would then occur through brittle faulting of the upper crust and ductile deformation of the lower crust. If the amount of extension is, to a first approximation, constant with depth through the whole thickness of the crust, the crustal radioactive contribution would decrease linearly with the amount of crustal thinning whatever the radiogenic sources distribution model adopted (Figure 8, Curve C). If the extension affects mainly the deep crust (Bott, 1971; Bott and Dean, 1972), the decrease in the crustal radioactive contribution is difficult to assess because it depends largely on the crustal deformation and radiogenic source distribution models adopted; it would be less than for the case of a uniform extension of the crust if radiogenic sources are mainly concentrated in the upper crust materials (Figure 8, Curve B).

Surface erosion must be eliminated as a possible process of crustal thinning under the Western Approaches margin because there is evidence that no erosion occurred before and during rifting in the central trough of the rift system (Montadert et al., this volume). One possible explanation of the large reduction of the surface heat flux is that the dominant process of crustal thinning under the margin was crustal extension. In this respect, assuming that the approximate one-half reduction of the crustal thickness under the continental slope and rise of the Western Approaches margin is a result of a purely extensive deformation affecting uniformly the whole thickness of the crust, the predicted change in the crustal contribution $Q_{c}$ is a reduction of also about one-half (applying Curve $C$ in Figure 8 ), which is within the range of the estimated reduction values in Table 2 . Such a large extension of the original continental crust suggested by the interpretation above is much more than the 15 per cent extension estimated by Montadert et al. (this volume) from a reconstruction of the displacements of the tilted fault blocks along fault planes.

\section{ACKNOWLEDGMENTS}

We thank J. Francheteau for reading the manuscript, D. Roberts and L. Montadert for their encouragements, and D. Carré and Y. Potard for technical assistance. 


\section{REFERENCES}

Artemjev, M.E. and Artyushkov, E.V., 1971. Structure and isostasy of the Baikal rift and the mechanism of rifting, $J$. of Geophys. Res., v. 76, p. 1197-1211.

Bertaux, M.G., Bienfait, G., Bottinga, Y., Fontaine, J., Guyot, G., Jolivet, J., Kast. Y., Meunier, J., Ottlé, J., Perrier, G., Poupinet. G., and Vasseur, G., 1978. Nouvelles déterminations du flux géothermique en France. Comptes Rendus de I'Académie des Sciences de' Paris, v. 286, p. 933-936.

Bickle, M.J., 1978. Heat loss from the earth: a constraint on Archean tectonics from the relation between geothermal gradients and the rate of plate production, Earth and Planet. Sir. Lett., v. 40, p. $301-315$.

Bott, M.H.P., 1971. Evolution of young continental margins and formation of shelf basins. Tectonophysics, v. 11, p. 319-327.

Bott, M.H.P. and Dean, D.S., 1972. Stress systems at young continental margins, Nature, v. 235, p. 23-25.

Bullard, E.C., 1954. The flow of heat through the floor of the Atlantic ocean, Proceed of the Roy. Soc. of London, Ser. A, v. 222 , p. $408-429$.

Closs. H., 1939. Hebung. Spaltung, Vulkanismus, Geologische Rundschau, v. 30, p. 405-527.

Colette, B.J., 1968. On the subsidence of the North Sea area. In Geology of shelf areas: Edinburgh and London (Donavan, Oliver and Boyd), p. 15-30.

Daignères, M. and Vasseur, G., in press. Détermination et interprétation du flux géothermique à Bournac (Haute Loirc), Annales de Giophysique.

Falvey, D.A., 1974. The development of continental margins in plate tectonic theory, Austral. Petrol. Explor. Assoc., v. 14, p. 95-106.

Gable, R., 1977. Ebauche d'une carte du flux géothermique de la France. Résumé des principaux résultats scientifiques et techniques du Service Géologique National pour 1976 , Editions du Bureau de Recherches Géologiques et Minières, Paris, p. 121-122.

Gerard, R., Langseth, M.G., and Ewing, M., 1962. Thermal gradient measurements in the water and bottom sediment of western Atlantic, J. of Geophys. Res., v. 67, p. 785-803.

Hurtig, E. and Oelsner, C., 1977. Heat flow, temperature distribution and geothermal models in Europe: some tectonic implications. Tectonophysics, v. 41, p. 147-156.

Jessop, A.M., Hobart, M.A., and Sclater, J.G., 1976. The world heat flow data collection. 1975, Geothermal service of Canada; Energy, Mines and Resources Canada, Earth Physics Branch, Ottawa, v. 5, p. 125.

Kono, Y. and Yoshii, J., 1975. Numerical experiments on the thickening plate model, J. of Phys. of the Earth, v. 23, p. 63-75.
Lachenbruch. A.H., 1968. Preliminary geothermal model of the Sierra Nevada, J. of Geophys. Res., v. 73, p. 6977-6989.

Langseth, M.G., 1965. Techniques of measuring heat flow through the ocean floor. In Lee, W.H.K. (Ed.), Terrestrial heat flow: Geophysical Monograph series, Am. Geophys. Union, v. 8, p. 58-77.

Montadert, L., Winnock, E., Delteil, J.R., and Grau, G., 1974. Continental margins of Galicia-Portugal and Bay of Biscay. In Burk, C.A and Drake, C.L. (Eds.). The Geology of continental margins: New York (Springer-Verlag), p. 323-342.

Morton. W.H. and Black. R., 1975. Crustal attenuation in Afar. In Pilger, A. and Rösler, A. (Eds.), Afar Depression of Ethiopia: Stuttgart (Schweizerbart'sche Verlagsbuchlandlung), v. 1, p. 55-65.

Pautot, G., Renard, V., Auffret, G.A., Pastouret, L., and De Charpal, O., 1976. A Granite cliff deep in the North Atlantic, Nature, v. 263, p. 669-672.

Pugh. D.T., 1975. Deep-sea tempcrature variations and their influence on heat-flow measurements, Earth and Planet. Sci. Le'tl., v. 27, p. $121-126$.

Ratcliffe, E.H., 1960. The thermal conductivities of ocean sediments, J. of Goophys. Res., v. 65. p. 1535-1541.

Ringwood, A.E. and Green, D.H., 1966. An experimental investigation of the Gabbro-Eclogite transformation and some geophysical consequences, Tectonophysics, v. 3, p. 383-427.

Roy, R.F., Blackwell, D.D. . and Birch, F., 1968. Heat generation of plutonic rocks and continental heat flow provinces, Earth and Planet. Sci. Lett., v. 5, p. 1-12.

Sclater, J.G. and Miller, S.P.. 1970. The relationship of heat flow, bottom topography and basement relief in Peake and Freen deeps, northeast Atlantic, Tectonophysics, v. 10, p. 283-300.

Sibuet, J.C., Ryan, W.B.F., Arthur, M., Barnes, R., Blechsmidt, G.. De Charpal, O.. de Graciansky, P.C., Habib, D., Jaccarino. S., Johnson. D., Lopatin, B.F., Maldonado, A., Montadert, L., Moore, D.G., Morgan, G.E., Mountain, M., Réhault, J.P.. Sigal, J., and Williams, C.A., in press. Deep drillings results of Leg 47B (Galicia Bank area) in the framcwork of the early evolution of the North Atlantic Ocean, Philosophical Trans. of the Rov. Soc. of London.

Sleep. N.H., 1971. Thermal effects of the formation of Atlantic continental margins by continental break up, Geophys. J. of the Roy. Astron. Soc., v. 24, p. 325-350.

Tammemagi, H.Y. and Wheildon, J., 1974. Terrestrial heat flow and heat generation in south-west England, Geophys. J. of the Roy. Astron. Soc., v. 38, p. 83-94.

von Herzen, R. and Maxwell. A.E., 1959. The measurements of thermal conductivity of deep-sea sediments by a needle-probe method. J. of Geophys. Res., v. 64, p. 1557-1563.

von Herzen, R.P. and Uyeda, S., 1963. Heat flow through the eastern Pacific ocean floor, J. of Geophys. Res., v. 68, p. $4219-4250$ 